\title{
$\begin{array}{r}\text { WAGENINGEN } \\ \text { UNIVERSITY \& RESEARCH } \\ \hline\end{array}$
}

\section{The environmental nation state in decline}

$$
\text { Mol, A. P. J. }
$$

This article is made publically available in the institutional repository of Wageningen University and Research, under article 25 fa of the Dutch Copyright Act, also known as the Amendment Taverne.

Article $25 \mathrm{fa}$ states that the author of a short scientific work funded either wholly or partially by Dutch public funds is entitled to make that work publicly available for no consideration following a reasonable period of time after the work was first published, provided that clear reference is made to the source of the first publication of the work.

For questions regarding the public availability of this article, please contact openscience.library@wur.nl.

Please cite this publication as follows:

Mol, A. P. J. (2016). The environmental nation state in decline. Environmental Politics, 25(1), 48-68. DOI: 10.1080/09644016.2015.1074385

You can download the published version at:

https://doi.org/10.1080/09644016.2015.1074385 


\title{
The environmental nation state in decline
}

\author{
Arthur P.J. Mol* \\ Environmental Policy group, Wageningen University, The Netherlands
}

\begin{abstract}
The environmental nation state is not a formal category but a substantive one. The current set of national environmental state institutions originated in the late 1960s/1970s but has since changed in character. Many scholars note that since the new millennium, the environmental nation state in OECD countries is losing power and authority and is thus in decline, in line with wider concerns about the positions of states versus markets under conditions of (neo-liberal) globalisation. Assessing the decline of environmental nation state authority, three conclusions are drawn. States do not lose power in all sectors vis-à-vis markets. Hence, environmental nation state decline does not follow a general tendency. Second, the decline of environmental nation state powers cannot be equated with less effective or lower levels of environmental protection, as other environmental authorities have stepped in, and the jury is still out on their environmental effectiveness. Third, declining powers of environmental nation state institutions increasingly become a selffulfilling prophecy of environmental policymakers, but non-state environmental authorities cannot take over all environmental state functions.
\end{abstract}

Keywords: state capacity; state authority; private governance; environmental performance; globalisation

\section{Introduction}

There is wide concern and criticism among environmental advocates regarding the poor successes, declining capacity and power, and waning priorities of nation state authorities in coping with current local and global environmental problems. According to these advocates, environmental state agencies and ministries are proving increasingly unable to develop, implement, and improve policies, plans, and measures that redirect societal and economic developments towards sustainability. This concern and criticism is more than the usual qualifications of environmental advocates who never consider the grass green enough and/or strategically operate an apocalyptic horizon of failing environmental states to move public opinion. Quite a number of environmental social scientists have joined this assessment of decreasing capacity and powers of environmental nation state authorities (e.g. Falkner 2003, Arnouts and Arts 2009, Anthoff and

*Email: arthur.mol@wur.nl 
Hahn 2010, Kraft and Vig 2010), although their analyses and assessments of causes and consequences vary. Many scholars imply that decreasing environmental state capacity and power affect environmental protection levels, reiterating the importance of state institutions for delivery of public goods. Others have noted that the environmental state is not the only set of organisations and institutions with authority to deal with environmental burdens (e.g. Spaargaren and Mol 2008).

The claim of weakening or incapable environmental nation state institutions seems to be part of wider concerns with the 'infrastructural power' (Mann 1984) of states and the changing position of states versus markets in the new millennium. Some scholars claim that under neo-liberal globalisation, the strengthening of the power and influence of (global) market institutions came together with, at best, the stagnating and even often-declining capacity, reach, and powers of state institutions. However, that conclusion is not evident in respect of all agendas, as the recent regaining by political institutions of influence and powers over global financial markets proves. ${ }^{1}$ Under neo-liberal globalisation, some state agendas seem to be more affected then others. Against this background, I focus here on two questions. Is there in fact a stagnating or even waning role, capacity, and power of environmental state authorities in OECD countries? Moreover, what would a decline of the environmental authority of nation state institutions mean for environmental problem solving? Hence, I aim here to qualify the weakening of the nation state environmental authority and assess what this means for managing prevailing environmental burdens. In the next section, I analyse the (historical) emergence and development of environmental state institutions before analysing why this state decline is specific to the environment. I then evaluate the idea that this state decline affects environmental performance. Finally, I discuss how we should normatively assess 'shrinking' environmental nation state powers.

I end this introduction with a short note on concepts and delineation. In analysing what has happened with state authority in coping with environmental agendas, I will use the concept 'environmental state' in a rather analytical (and non-normative) way (cf. Mol and Buttel 2002), akin to the concept of 'ecological state' or 'ecostate' (cf. Meadowcroft 2005). The modern environmental state refers to the set of governmental organisations, institutions, and practices (i.e. what James Meadowcroft refers to as 'structures and arrangements') that have been developed and installed over a five-decade period to cope with the modern environmental burdens that have emerged on public and political agendas since the 1960s, initially in OECD countries and later more globally. This set of state organisations, institutions, and practices differs in form, size, outlook, and functioning according to time and place. Hence, the environmental state is not an ahistorical formal category, but rather a substantive one. In its modern form (on which I will concentrate), it developed in the 1960s and 1970s in the OECD countries, spread to wider geographies in the following two decades, and changed in character. We will have to see - and will start analysing here - how long it 
will last, where, and with what prospects. My core focus is on national state institutions in $O E C D$ countries.

\section{Environmental nation state decline}

The idea of environmental nation state stagnation and decline can only be understood with a historical perspective. Roughly speaking, the environmental state in the OECD countries has gone through at least four phases. In these different historical phases, the outlook and configuration of environmental state institutions reflect the specifics of national historical contexts, policy styles, environmental threats, and national economic and political developments, as various historical and comparative studies of national environmental policy and management have shown (e.g. Hays 1987, Ahuis 2004, Hillstrom and Hillstrom 2010, Steinberg and VanDeveer 2012). Whereas the phases have thus not developed exactly synchronously in all OECD countries, and national environmental state prospects are 'coloured' by national circumstances, for the purpose of this discussion I sketch the main tendencies and periods and neglect individual particularities and outliers.

\section{Rise and institutionalisation}

Until the late 1950s/early 1960s, most developed states had installed only marginal state organisations and institutions to cope with environmental destruction, often initially at local levels. Nature protection and nature conservation was a main focal point since the late nineteenth and early twentieth centuries in Europe, the USA, and Russia, and some national health-related organisations and institutions were in place (e.g. on drinking water, urban waste collection and dumping, workplace safety, and health). Alternatively, to put it in Samuel Hays (1987) terminology, 'beauty' and 'health' received some state attention, but 'permanence' did not (yet). Most of the modern environmental threats related to 'permanence', such as industrial and agricultural surface and ground water pollution, air pollution, toxic chemicals, and soil pollution, as well as the more international and global environmental threats, were left unaddressed.

The period from the 1960s until the early 1980s could be marked as the era of establishment and institutionalisation of the modern environmental nation state. Triggered by wide public protests and local and national environmental non-governmental organisations (NGOs), most OECD countries constructed governmental environmental institutions and capacity in the form of: national environmental laws and regulations; national governmental organisations (ministries, environmental protection agencies, and environmental advisory councils); national environmental planning and policy instruments such as Environmental Impact Assessments; environmental inspection, control, and enforcement; and others (see Binder 2002, Busch et al. 2005). These state institutions and organisations were constructed most visibly at the nation state 
level, but often had equivalents or operational arms at lower governmental levels. The division of tasks and responsibilities between these governmental levels differed by country, depending among others on culture, size, and state form.

The 1980s can be seen as a decade of stagnation of environmental state capacity building due to two interdependent reasons. First, the neo-liberalisation debates and pressure, most strongly felt in the USA and the UK but with wider outreach, hampered further building, expansion, and detailing of environmental state capacity (McCormick 1991, Kraft and Vig 2010). Second, disappointment with the results of environmental state institutions and organisations in mitigating environmental devastations resulted in debates on environmental state failure (e.g. Jänicke 1986) and reflections on the poor performance of a 'nation state strategy' in addressing environmental infringements. Budgets, human resources, new legislation, and policies stagnated and occasionally came under threat, especially at the national level, marking a type of cap on two decades of rapid environmental state expansion. However, although environmental deregulation and privatisation were frequently mentioned and even planned in those years, in retrospect, no overall shrinking or decline of environmental nation state institutions and capacities can be identified in industrialised countries during the 1980s (Collier 1997, Mol and Buttel 2002).

The 1990s, then, can best be marked as an era of environmental state redefinition, reinvention, regained legitimation, and increased power and capacity in two ways. First, the environmental state became much further embedded in and connected to wider segments of society and the economy. This expanded scope manifested itself in new steering strategies and instruments (or governance models) and in participation of non-state actors in all types of partnerships, hybrid institutions, and participative governance models. These models, strategies, and instruments meant a stronger embeddedness of environmental nation state institutions in societies (including the economy), which further strengthened (rather than weakened or undermined) the operational arms of the environmental nation state. Concepts of regulatory reinvention in the USA (Rosenbaum 2000, Kraft and Vig 2010) or political modernisation in Europe (Jänicke 1993, Van Tatenhove et al. 2000) capture this renovation of the environmental nation state. Second, international and global environmental agendas emerged strongly, and the environmental nation state became refortified and legitimised through addressing international and global challenges via international cooperation. International environmental treaties (UNEP 2012, p. 464), international environmental summits, international environmental organisations and networks, and international environmental programs and support mushroomed and further expanded and legitimised the environmental nation state powers. Most of these international actions were developed, monitored, funded, implemented, and verified primarily or mainly through the international state system. Together, these developments set aside debates and questions on the need, powers, adequacy, and capacity of environmental nation state institutions and organisations 
in addressing environmental burdens, and arguably extended the age of the Environmental Leviathan (Paehlke and Torgerson 1990).

\section{Stagnation and decline}

In the remainder of this article, I will further assess the fourth, current phase in the development of the modern environmental nation state in OECD countries. My thesis is that this phase should be labelled one of stagnation and relative decline of the environmental nation state. In this phase, the power, capacity, and impact of the environmental nation state in most OECD countries are stagnating and, in particular countries, even declining. Alternatively, to put it in terms of Knill et al. (2009), the density and intensity of environmental nation state operations are affected. Density refers to the number of policies and interventions of the environmental nation state institutions, intensity to the strictness/stringency (or when subsidies are involved, generosity) of environmental nation state interventions. Indicators or proxies that 'measure' such affected density and/or intensity include, for instance, the following: state capacities in terms of number of national staff and budgets at environmental state institutions; the output and innovation of stringent environmental laws, of new, effective environmental policy instruments, and of ambitious environmental plans; effective implementation of environmental state decisions; quality and efficiency of environmental state administration; adequacy of nation state institutions in addressing new environmental challenges; environmental Weberianness (Rauch and Evans 2000); and relative power of environmental state institutions vis-à-vis other (nation-)state institutions and vis-à-vis major private parties. However, such indicators/proxies are not easy to quantify and compare across time, and there is little monitoring of such indicators and proxies. ${ }^{2}$

There is, of course, longitudinal data on environmental quality, emissions, and performance of OECD countries, such as those compiled by the Yale centre of Environmental Policy (Hsu et al. 2014), from the World Resources Institute database, or from UNEP's Global Environment Outlook data portal. However, these longitudinal data sets cannot be related back to national state capacity or state performance, as many other variables intervene. Other studies have compiled comparative data sets that are related to state capacity, but often these data were not collected longitudinally or were not collected over a sufficiently long period (e.g. Weidner and Jänicke 2002, Esty and Porter 2005, Jacob and Volkery 2006). There hardly exist longitudinal national databases with indicators on environmental states covering the past one-and-a-half decades or so. More-qualitative country case studies do exist that interpret and assess environmental state capacities, often regarding specific environmental issue areas. I will present three longitudinal databases and some qualitative country case studies to make a reasonable case for the thesis of environmental nation state stagnation/decline in OECD countries, under the current condition of an expanding environmental agenda. 
Environmental capacities as measured by the number of staff of national Ministries for the Environment and/or national environmental protection agencies between the 1990s and early 2010s show some variation among the different OECD countries (Table 1). ${ }^{3}$ A group of countries show stagnation in staff numbers in national environmental authorities (the USA, Japan, Finland, Sweden, Norway). Another group of countries show declining staff numbers in national ministries but some increase in staff at executive environmental agencies (Germany, Austria, New Zealand). A third group of countries, including the UK, the Netherlands, Denmark, Canada, and Australia, experience (sharp) declines in number of staff at national environmental authorities (but not always at agencies). A second indicator documents public environmental expenditures. Between 1995 and 2012 in the EU, public environmental expenditures as percentages of total government expenditures and as percentage of GDP (since 2002) have been stagnating or decreasing for most European OECD countries, with a single exception Sweden (European Commission/Eurostat 2011, Eurostat 2014). The USEPA budget in constant dollars also stabilised between 1990 and 2008 (Kraft and Vig 2010, p. 378).

The World Economic Forum has surveyed business leaders of different countries over a number of years on the stringency of national environmental regulation and the stringency of national environmental enforcement (ranging from $1=$ lax to $7=$ stringent; e.g. WEF 2014, p. 56-57). Average perceived levels of environmental regulatory and enforcement stringency for OECD countries have stayed rather stable, whereas those of all countries have increased between 2004/2005 and 2013/2014 (see Figure 1). OECD countries with decreasing national staff capacity (see Table 1) have systematically a lower perceived environmental (regulation and enforcement) stringency than do those OECD countries with stagnating environmental staff capacity (on average a $0.4 / 0.5$ difference over the years).

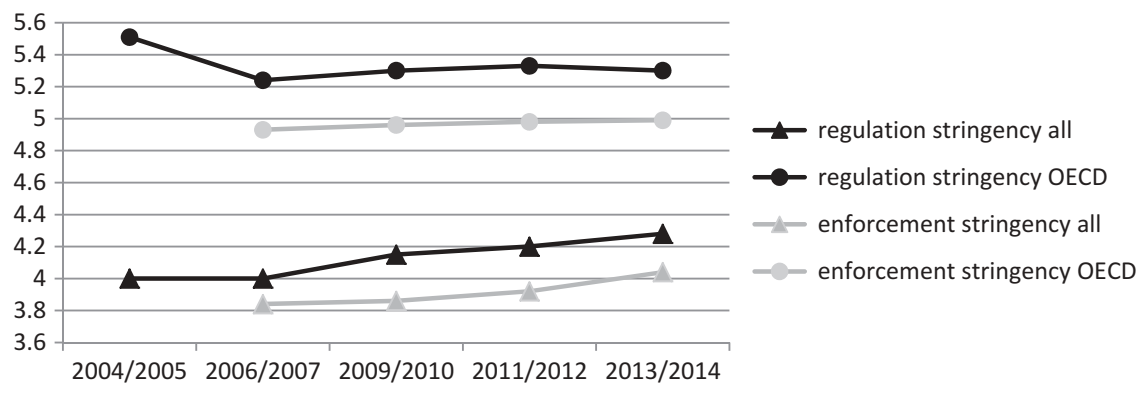

Figure 1. Company CEO perceptions of stringency of environmental regulation and enforcement in OECD countries and all countries (scale $1=$ lax, $7=$ stringent). Source: World Economic Forum database. 
Table 1. Number of staff of national Ministries of the Environment/Environmental Protection Agencies in the 1990s and 2010s for selected OECD countries.

\begin{tabular}{|c|c|c|c|}
\hline Country & $\begin{array}{l}\text { Number of } \\
\text { staff } 1990 \text { s }\end{array}$ & $\begin{array}{l}\text { Number of staff } \\
2010 \mathrm{~s}\end{array}$ & Source \\
\hline Australia* & Declining & Declining & $\begin{array}{l}\text { Annual reports of } \\
\text { ministries }\end{array}$ \\
\hline \multicolumn{4}{|l|}{ Austria } \\
\hline $\begin{array}{l}\text { - Ministry of Land, } \\
\text { Forest, Environment, } \\
\text { and Water (LFEW; } \\
\text { overall) }\end{array}$ & 3577 (1995) & $2540(2013)$ & $\begin{array}{l}\text { Andersen and Liefferink } \\
\text { (1997, p. 89); website } \\
\text { UBA; Bundeskanzleramt } \\
\text { data }\end{array}$ \\
\hline $\begin{array}{l}\text { - Ministry of LFEW: } \\
\text { central office }\end{array}$ & $940(2003)$ & $853(2013)$ & \\
\hline $\begin{array}{l}\text { - Federal Environmental } \\
\text { Agency UBA }\end{array}$ & $200(1995)$ & 479 (2014) & \\
\hline \multicolumn{4}{|l|}{ Canada } \\
\hline - Environment Canada** & $\pm 10,000(1991)$ & $\begin{array}{l}6973(2010) \\
6400(2014)\end{array}$ & $\begin{array}{l}\text { Enros (2013); annual } \\
\text { Report on Plans and } \\
\text { Priorities EC }\end{array}$ \\
\hline \multicolumn{4}{|l|}{ Denmark } \\
\hline $\begin{array}{l}\text { - Danish Ministry of the } \\
\text { Environment (central) }\end{array}$ & $138(2002)$ & $70(2008)$ & $\begin{array}{l}\text { Andersen and Liefferink } \\
(1997, \text { p. } 259) \text {; website }\end{array}$ \\
\hline $\begin{array}{l}\text { - Danish MoE, incl. } 7 \\
\text { decentral. offices }\end{array}$ & 3400 (1999) & $2575(2006)$ & $\begin{array}{l}\text { Danish EPA; OECD } \\
\text { Environmental }\end{array}$ \\
\hline $\begin{array}{l}\text { - Danish EPA } \\
\text { Finland }\end{array}$ & 450 (1996) & $450(2014)$ & performance review \\
\hline $\begin{array}{l}\text { - Ministry of the } \\
\text { Environment }\end{array}$ & 295 (1994) & $280(2014)$ & $\begin{array}{l}\text { Andersen and Liefferink } \\
\text { (1997, p. 129); website } \\
\text { MoE }\end{array}$ \\
\hline \multicolumn{4}{|l|}{ Germany } \\
\hline $\begin{array}{l}\text { - Bundesministerium für } \\
\text { Umweltschutz, } \\
\text { Naturschutz, und } \\
\text { Reaktorsicherheit }\end{array}$ & $>800(1993)$ & $<700(2013)$ & $\begin{array}{l}\text { Websites } \\
\text { Bundesministerium and } \\
\text { UBA }\end{array}$ \\
\hline $\begin{array}{l}\text { - Federal Environmental } \\
\text { Agency UBA }\end{array}$ & $1000(2004)$ & $1500(2014)$ & \\
\hline \multicolumn{4}{|l|}{ Japan } \\
\hline $\begin{array}{l}\text { - Ministry for the } \\
\text { Environment }\end{array}$ & $1230(2001)$ & $1200(2013)$ & $\begin{array}{l}\text { AECEN website; Barrett } \\
(2005 \text {, p. 31) }\end{array}$ \\
\hline \multicolumn{4}{|l|}{ Netherlands } \\
\hline $\begin{array}{l}\text { - Directorate-General for } \\
\text { the Environment DGM }\end{array}$ & $\begin{array}{l}1000 \text { (early } \\
1990 \text { s) }\end{array}$ & $300(2014)$ & Personal information \\
\hline \multicolumn{4}{|l|}{ Norway } \\
\hline $\begin{array}{l}\text { - Ministry of the } \\
\text { Environment }\end{array}$ & 270 (1994) & $260(2014)$ & $\begin{array}{l}\text { Andersen and Liefferink } \\
\text { (1997, p. 327); websites }\end{array}$ \\
\hline $\begin{array}{l}\text { - Pollution Control } \\
\text { Agency }\end{array}$ & 238 (1994) & $325(2014)$ & $\begin{array}{l}\text { ministry and Pollution } \\
\text { Control authority }\end{array}$ \\
\hline
\end{tabular}


Table 1. (Continued).

\begin{tabular}{|c|c|c|c|}
\hline Country & $\begin{array}{l}\text { Number of } \\
\text { staff } 1990 \text { s }\end{array}$ & $\begin{array}{c}\text { Number of staff } \\
2010 \text { s }\end{array}$ & Source \\
\hline $\begin{array}{l}\text { New Zealand } \\
\text { - Ministry for the } \\
\text { Environment }\end{array}$ & $115(1991)$ & $\begin{array}{l}330(2009) \\
270(2013)\end{array}$ & $\begin{array}{l}\text { Website Ministry for the } \\
\text { Environment }\end{array}$ \\
\hline Sweden & & & \\
\hline $\begin{array}{l}\text { - Ministry of } \\
\text { Environment and } \\
\text { Natural Resources }\end{array}$ & $150(1996)$ & 168 (2013) & $\begin{array}{l}\text { Andersen and Liefferink } \\
\text { (1997, p. 51): SEPA } \\
\text { website; Government }\end{array}$ \\
\hline $\begin{array}{l}\text { - Swedish EPA } \\
\text { UK }\end{array}$ & $500(1996)$ & $530(2014)$ & Offices Yearbook \\
\hline - DEFRA & 7000 (2002) & 2100 (2014) & UK government website \\
\hline - Environment Agency & $10,500(2001)$ & $\begin{array}{l}13,181(2010) \\
10,600(2014)\end{array}$ & \\
\hline $\begin{array}{l}\text { USA } \\
\text { - USEPA }\end{array}$ & $17,910(1995)$ & $18,740(2010)$ & Census data \\
\hline
\end{tabular}

Note: Some countries provide numbers in full-time equivalents and others in head count, making numbers between countries not directly comparable. Two moments in time are presented, which has the danger of non-representative data for a larger period. I have checked this for current 2013/2014 data (see also http://epanet.ew.eea.europa.eu/european_epas) but often was not able to do that for data in the 1990s.

*The Ministry has changed name and composition repeatedly. The environmental staff number of the Australian Capital Territory has been declining since 1998, with the exception of fiscal year 2005/ 2006.

**Numbers decreased sharply until the late 1990 s to below 5000 , increased to 7000 in 2010 , and then decreased again.

In addition to the limited quantitative evidence, there are many qualitative studies that support the observation of environmental nation state institutions in stagnation or decline. Writing on subjects such as neo-liberalising nature (e.g. Castree 2008), policy/governance failure on the environment (e.g. Mercer et al. 2007, Helm 2010), environmental deregulation and privatisation (e.g. Mert 2012), and the hollowing out of the state (e.g. Aldred 2012), numerous authors have identified and analysed the declining authority of central state institutions in handling environmental problems. In these case studies and qualitative evidence, some OECD countries figure more prominently with declining environmental state authorities (Canada, Australia, the Netherlands, the USA, the UK lately, Denmark, Italy) than others (Germany, Sweden, New Zealand). Additionally, from the case studies, nation state decline and failure seem especially pertinent for the new environmental agendas that emerged in the 1990s and later. The low capacity, authority, and performance of environmental nation state institutions in addressing these new environmental agendas are related to a failure to take up these environmental protection tasks effectively in the first place. Climate change, biodiversity loss, pollution of the oceans, overfishing of the oceans, illegal trade in waste, and protection of the polar regions are a few of the more 
recent environmental challenges for which national state institutions have proved not to be the key regulators. In other words, central state institutions have not successfully developed or implemented (new) approaches, strategies, capacities, and instruments to address these challenges. Here, stagnating or regressing nation state capacity is not the conscious and deliberate relocation of environmental capacity and responsibilities to other public and private environmental authorities for reasons of efficiency, effectiveness, and institutional fit, as is occasionally claimed for issues such as waste collection or drinking water provisioning (see below).

\section{Explaining stagnation/decline of the environmental nation state}

There seems to be a prevailing opinion that, under contemporary globalisation and neo-liberalisation, states lose power to economic institutions and actors. Since the 1990s, many claim that private market authority is gaining ground vis-à-vis public authority (e.g. Ohmae 1995, Strange 1996, Cutler et al. 1999, Beck 2005). However, the idea of an overall diminishing public authority of the nation state needs to be balanced. Elsewhere, scholars have argued convincingly that economic globalisation:

- results not in the overall decline of the state, but rather in a partial replacement of state authority by private market authority (Sassen 2006);

- goes together with denationalising of state capacities and growing influence of political authorities beneath and beyond the national state (Beck 2005);

- leads to major internal transformations in nation state authority, as some state sectors (e.g. the presidency, the treasurer, some executive branches) become strengthened and others become weaker (representative institutions, regulatory and legislative branches, environmental and other agencies); and

- does not equal poor protection of public goods, as market and moral authorities can successfully step in (e.g. Pattberg 2007, Spaargaren and Mol 2008).

The 2007/2008 financial crisis in the USA and later in Europe - and the crucial role of nation states, national central banks, and EU institutions in containing that crisis and restoring some control and regulatory oversight over private financial institutions - contributed to the notion of a 'return of the nation state'. However, signs of nation state institutions (re)gaining ground seem absent from the environmental arena. There seem to be few serious attempts and actions to enhance substantially the power, capacity, and authority of environmental nation states in OECD countries.

\section{The exception of the environmental nation state}

Therefore, whereas economic globalisation does not automatically result in an overall stagnation or decline of nation state/public authority and capacity, in 
many OECD countries, the environmental nation state - the set of national state environmental organisations and institutions - has failed to increase power and capacity over approximately the last decade and a half. Four arguments can help to understand this stagnation/decline of, in particular, national environmental state institutions (i.e. vis-à-vis national state institutions in other sectors/branches, vis-à-vis state institutions at sub- and supranational levels, and vis-à-vis non-state environmental institutions). It is understood that not every reason has equal explanatory power for every nation state.

First, and following the idea of sustainable development, one of the new strategies of the 1980s to cope with state failures was what has been labelled external integration: the idea (and practice) that environmental infringements could only be addressed successfully when sectoral state agencies, institutions, and policies (economic, finance, agriculture, industry) were integrated with environmental ones (Jordan and Lenschow 2010). The previously relatively autonomous/separate environmental state institutions and organisations increasingly started to share and mix tasks/responsibilities with sectoral (economic, financial, agricultural, etc.) equivalents, or were even merged with those sectoral equivalents into integrated institutions and organisations. During the heyday of environmental concern in the 1990s, this worked well and gave state environmental advocates significant influence to redesign/green other state institutions. In particular, the influence of environmental state institutions and programs on economic (sectoral) development, financial policies, foreign and international cooperation policies, and energy policies significantly strengthened the environmental agenda. When times changed and environment moved to the bottom of the public and political agendas towards the end of the 1990s, some of these integrated institutions concentrated again on their core, non-green functions.

Environmental policy integration is of course seldom a win-win process and often has trade-offs: there may be real winners and losers (Lenschow 2002, p. 34). Alternatively, as Liberatore states, 'the concept of integration assumes a form of reciprocity' (1997, p. 119). However, unless the different components, in this case sectoral and environmental interests, have similar weight and power, the output will not be a policy that is integrated with respect to environmental aspects but instead a policy that dilutes environmental interests. When environmental interests started losing power in the national state bureaucracies and politics (in the late 1990s and beyond), state environmental policymaking and implementation institutions became marginalised (Mol 2004). Integration proved then often a Trojan horse for the environmental nation state. In the Netherlands, environmental integration resulted in the merging in 2010 of two national ministries into the Ministry for Infrastructure and Environment, with a Minister for Infrastructure and a lower-level, less-powerful Secretary of State for Housing and Environment (notice the sequence!). Additionally, in many countries, the greening of economic policies in the 1990 s turned into requirements that environmental policies be economically sound in the 2000s. For Germany, Müller (2002) 
concluded that the Environment Ministry did not possess the institutional standing in the government and the procedural tools to intervene in the work of other ministries. Hey (2002) analysed the failure of environmental taxation on heavy goods vehicles in Europe due to the power of financial ministries. In contrast, in the UK integration of environment in other policy domains from the mid-1990s to the early 2000s does not show this weakening of the environmental state.

Second, international environmental cooperation and policy provided a major legitimacy for and empowerment of environmental state institutions in the 1990s. The Institutions for the Earth (Haas et al. 1993) were primarily institutions of nation state collaboration. However, by the turn of the millennium, these statebased institutions started to lose power, attractiveness, success, and thus legitimacy. The architecture of the international state system proved not (or no longer) capable of handling the global environmental challenges we are confronted with, not unlike how environmental nation states individually failed to cope with the national environmental challenges in the 1980s. In the third millennium, new models of global environmental collaboration were called upon and partly emerged, ranging from new forms of global environmental state collaboration and organisation via all types of hybrid institutions to non-state transnational network institutions that go beyond and outside collaborating environmental nation states.

Arguably, the problems with the entering into force of the Kyoto protocol and with the negotiations of its successor are among the best illustrations. Advances and innovations of global climate change policies are not so much made by collaborating nation states within the framework of the UNFCCC but rather by municipalities and mayors (Bouteligier 2013), private companies and market parties, NGOs, and others. Two global financial crises enhanced state powers and capacity in the financial sector to diminish and contain the role of the private sector. However, until now, the global environmental crises did not 'force' larger environmental nation state capacities; nor did they further 'contain' the drivers of climate change.

Third, with globalisation, environmentally relevant practices (practices causing environmental devastation as well as practices preserving the environment) are increasingly caused, governed, and determined by networks and flows that criss-cross national borders and jurisdictions. Networks and flows of transport and mobility, of energy and other natural resources, of products and services, of pollution and waste, to name but a few, have become architects of the contemporary environmental profile. As Spaargaren et al. (2006) illustrated for different environmental issues, this prompts other environmental governance authorities than (collaborating) nation states. City networks, business networks, global production and supply networks, global public-private partnerships, networks of labelling/certification that combine market and moral authority, to name but a few, seem to be leading the innovation in (global) environmental governance, as they have a structural 
affinity with the flow-and-network logic of current transnational environmental challenges. Nation state institutions are definitely actors in these new governance networks that aim to manage environmental flows. However, whereas in the 1980s and 1990s, environmental states managed to initiate, coordinate, lead, determine access to, and influence multi-stakeholder governance arrangements within states and between states, they prove less able to do so in the new millennium within transnational environmental governance networks as described above. Hence, these new global governance networks increasingly challenge conventional international environmental policymaking and implementation, and environmental nation states lose a large part of their positions as environmental governance network initiators, coordinators, gatekeepers, and connectors.

These new networked environmental governance arrangements beyond the nation state have been witnessed in the contexts of the sustainability regulation of aquaculture and captured fish (Bush et al. 2013), wood (Tysiachniouk 2012), biofuels (Mol 2010), organic agrofood (Glin et al. 2012), and other transnationally traded products. Multi-stakeholder initiatives, global value chain governance, and private certification schemes dominate sustainability governance, whereas (collaborating) nation states are playing a subsumed role or are even absent.

Fourth and finally, the perception of environmental nation state decline is also enhanced by the accountability structure in environmental politics. Under current conditions of globalisation, environmental nation states are still the prime institutions held accountable for environmental performance (especially in terms of impacts) in their territories or within their jurisdiction by equivalent (state) entities, by their domestic constituencies, and by globally operating non-state actors (international organisations, multinational companies, NGO networks, etc.). Even under current conditions, where - as indicated above - states have lost a great deal of power over ruling, regulating, detailing, and prescribing environmentally relevant activities within or related to their jurisdictions and territories, environmental nation states are the prime institutions held accountable. This accountability-without-power severely undermines the legitimacy of the environmental nation state through unfulfilled accountabilities of multiple types.

This contrasts with a number of new (i.e. non-state or hybrid) environmental institutions that were (until now) not as strongly held accountable for environmental performance. Additionally, if they are held accountable, it is rather in respect of outputs (what they actually do in terms of new policies, initiatives, instruments, strategies) and less so regarding the more troublesome outcomes (e.g. changing behaviour of polluters) and impacts (e.g. lower emissions, better environmental quality). Partnerships, hybrid institutions, roundtables, private NGO-business coalitions, city networks, lead firms in global value chain, civil society transparency institutions such as Transparency International or the Carbon Disclosure Project, to name a few, are not necessarily more successful in terms of environmental governance performance. However, as they lack the 
formalised and structured accountability mechanisms so characteristic of nation state environmental institutions, they are less vulnerable to criticism for substandard environmental performance.

\section{Balancing environmental nation state stagnation and decline}

This sobering portrait of the current environmental nation state should be qualified on three accounts. First, this stagnating or even declining power and capacity of the environmental nation state might be temporary, a specific phase in the history of how states handle environmental damage. Not unlike the stagnation in advancing and implementing the environmental agenda in the 1980s, OECD countries may also now face a temporary setback in environmental state building, followed by a new phase or reinvention. In other words, it remains to be seen how permanent this environmental nation state setback is.

Second, this contemporary decline does not mean that environmental nation state institutions have become irrelevant in absolute terms. Although Levy (2010) hypothesises that, compared with social policy, there could be very powerful votes for dismantling environmental policies as the desire to "claim credit' for deregulation outweighs the avoidance of blame, there exists little empirical evidence of the existence of such a process. Decades of environmental state institution building guarantee some inertia and continuity of the environmental nation state. Even today, massive 'environmental deinstitutionalisation' the breaking down and dissolving of nation state environmental institutions (e.g. Mol 2009) - or environmental policy dismantling (e.g. Korte and Jörgens 2012; Jordan et al. 2013) is still a rare phenomenon, as also evidenced by the selective environmental state capacity data presented above.

Third, declining capacity, interest/priority, and authority of the environmental nation state institutions on environmental agendas and threats is not automatically problematic for environmental sustainability. Some claim that centralised environmental policymaking provides more stringent outcomes than decentralised or cooperative forms (Weiburst 2009). Quite a number of 'conventional' local/national environmental threats emerged on the public and policy agendas in the 1970s and have successfully been put under some type of (state) control in OECD countries (e.g. safe drinking water, sewerage, acidification, solid waste, point-source surface water pollution, food poisoning, and deforestation). However, less nation state involvement does not mean less-effective problem solving, control, and management. Other institutions and actors, within and outside the environmental nation state, have taken over functions, tasks, capacities, and responsibilities of national state institutions through decentralisation, devolution, integration, privatisation, hybridisation, and internationalisation. As Weidner and Jänicke (2002, see also Jacob and Volkery 2006) conceptualise, national environmental capacity is more than nation state environmental capacity. Some scholars note the continuing (indirect) power and effect of environmental nation state institutions by claiming that these operate now in new governance 
arrangements (or partnerships such as green alliances) with other non-state actors and institutions, and with sub- and supranational political bodies on environmental protection (e.g. Conca 2005; Glasbergen et al. 2007). Environmental awareness-raising can be and is handled through environmental NGOs; solid waste collection and recycling is (partly) privatised to companies; environmental enforcement runs (also) via value chains, insurance companies, and private certification organisations; and environmental licensing and energy conservation programs are decentralised to municipalities. Although the relocation of these environmental tasks and responsibilities from nation state institutions to other public and private environmental authorities often goes together with - more or less fierce - debates about effectiveness, efficiency, and equity, the aim and often end result of such relocation is not necessarily a lower level of environmental protection, preservation, and performance. However, it is definitely a different form of institutionalisation of environmental protection.

That is also why OECD countries do not show an overall environmental deterioration, even though their nation state institutions seem to be losing environmental authority. In analysing the environmental performance data of OECD countries over the past two decades, most scholars agree that there has been a lack of sufficient progress in mitigating environmental pollution (e.g. greenhouse-gas emissions, pesticide use), resource efficiency and recycling (e.g. phosphate, energy, rare earths), and environmental quality (air, oceans, soils), either in total, per capita, or per unit of GDP. However, few can conclude that there has been an overall environmental deterioration in these countries on most indicators. The Environmental Performance Index of the Yale centre for environmental Law and Policy, among others, does not show deteriorating environmental performances for the group of OECD countries over the past decade (http:// epi.yale.edu/). Institutionalisation of environmental capacity in other than nation state institutions is part of the explanation.

In conclusion, the stagnation/decline of environmental nation states has come together with a hybridisation (Conca 2005) and diversification (Spaargaren and Mol 2008) of environmental authorities, both within the system of states and outside it. These developments suggest that stagnation/ decline of environmental nation state institutions does not map directly to apocalyptic horizons of failed environmental governance. Many other institutions, both state and non-state, have shown their power and authority in governing the environmental challenges of our time. In addition, many scholars have illustrated the power and effects of these non-(nation) state environmental institutions in governing environmental problems. Obviously, these alternative environmental institutions and authorities are not (yet) performing according to desired sustainability standards. However, there is no reason or historical 'evidence' to believe that a larger nation state environmental capacity would have done much better. This raises the question of whether we should be worried at all about a stagnating or declining nation state environmental capacity. As argued elsewhere (Mol 2007b) in different terms, I do 
think there are arguments to 'bring the environmental state back in', analytically and normatively.

\section{Bringing the environmental state back in}

Now that other environmental authorities below, above, and outside the nation state are increasing in importance, I conclude that it remains essential to bring the environmental nation state back into the equation of environmental protection for three reasons.

First, there is a strong double hermeneutics element in the analysis of weakening environmental nation states and emerging new non-state authorities. Social scientists have been conscious of double hermeneutics, that is, of the fact that social science studies and writings influence research objects for better or for worse. Increasingly, with the literature and studies on network governance, private governance, governance without government, partnerships, non-state-market-driven governance and others, environmental nation state organisations, and their officials/representatives appear increasingly to internalise these ideas by: legitimising and prioritising non-interventionist state environmental policies; showing a preoccupation with mediation and network construction instead of designing and implementing substantial and stringent environmental policies; reducing the until recently strong core of environmental experts and expertise within the environmental state while maximising the numbers of managers, mediators, and communicators; and outsourcing nation state tasks to subnational institutions and non-state parties. Shifts in environmental authority become an excuse or argument for an absence of environmental ambitions within national state environmental agencies, for a further weakening of environmental state institutions, for non-interventionist policies, for endless mediation and discussion, and for environmentally ineffective devolution and privatisation. In other words, shifts in authority may then result in a self-fulfilling prophecy of declining environmental state capacity. It is understood that specific sectors in society and specific political ideologies cherish and celebrate such developments, emphasising the impossibility of interventionist, preventive, and precautionary national environmental policies. In contrast to the environmental domain, there is little hesitation within state organisations and officials to be interventionist and preventive when issues of terrorism, security, economic stimulation, or financial crises are at stake.

Second, the environmental nation state needs to be foregrounded, as it is not interchangeable with other (non-state) environmental authorities in all respects. I do not want to argue that states have any pre-given higher morality, normatively preferable place, or formal ahistorical position in environmental protection arrangements. However, I do think that in contemporary environmental governance, states and state authorities require a conceptualisation that is fundamentally rather than marginally different (but not better) than those of other (private) actors and authorities. Bringing the environmental state back in 
means making conceptual room for the specificities of states and state authorities wherein environmental accountability, rule-altering behaviour, democracy, and balancing interests cannot be handled adequately and/or legitimately by non-state authorities. This is in line with Gerrefi et al. (2001, Mayer and Gereffi 2010), who conclude that private partnerships should not weaken or replace existing state programmes but should go together with a strong state that actively enforces environmental goals within and beyond their sovereign territory. Similarly, Seidman (2005) warns of the limitations of 'stateless' governance and for civil society replacing the state in taking up watchdog and control functions traditionally fulfilled by the state. The question then becomes: regarding what types of environmental issues, levels, and arrangements can state 'functions', tasks, and responsibilities be (partly) taken over by or mixed with other actors and authorities, and where do we witness (and thus need) the unique qualities of nation states and state institutions? Without claiming to provide a full and complete analysis, some essential environmental nation state functions can be identified. Meadowcroft (2007) provides an interesting start for such an analysis with respect to democracy, wherein he argues for the essential meta-governance role of representative institutions. Other nation state roles prove essential in handling environmental catastrophes such as nuclear disasters (e.g. Fukushima in 2011), the global spread of bird flu (2003/2004) or swine flu (2009), or major oil spills such as the Deep Horizon (2010). States are also key to constructing, codifying, and maintaining a level playing field in which environmental risk allocation is not squeezed towards vulnerable minorities, whether on a local or global level. Additionally, states are essential in preventing and punishing major criminal behaviour related to the environment, such as illegal toxic waste dumping, intentional food contamination (such as melamine in milk or glycol in wine), and IUU (illegal, unreported and unregulated) fishing.

With this set of specificities of environmental nation states, we nonetheless do not argue for (a return to) classical statist arrangements in environmental governance, as some of the 'simple modernity' state advocates seem to do. Under specific conditions, legitimacy, accountability, environmental effectiveness, interest balancing, and democracy can also be organised and safeguarded to a major extent through, for instance, global private authorities. However, in other cases, this is not desirable or possible, or the (non-monetary) costs and external effects would be too high. In those cases, environmental nation states and their democratic institutions should not withdraw into stagnation, mediation, facilitation, network management, and information exchange with respect to solving global environmental problems. Rather, in such cases, environmental states must be foregrounded in taking the authoritative lead in actions against environmental devastation.

Bringing the environmental state back in thus refers not only to an analytical project (bringing the environmental state back into the analysis of environmental governance) but also to a political project wherein environmental states, state 
organisations, and state officials dare to intervene and make a difference, and also when uncertainties, globalisation, and complexities make simple planning and causal goal-effect analysis out of the question. However - and this is my third point - the outlook, operations and power employment of the environmental state should be different compared with those of two decades ago. Globalisation requires an outward-looking cosmopolitan state in a transnational state system, not an inward-looking programme of narrow nationalist (environmental) protectionism. Environmental nation states should not limit operations to the 'nation state container', but should actively operate in, 'program', and connect with (cf. Castells 2009) global networks where global environmental flows are handled and managed. Nation states have started doing that to some extent with respect to global financial flows and security and terrorism; they should start doing similarly with respect to regulating environmental flows and protection. Connecting and programming different global networks regulating environmental flows cannot be left in the hands of private institutions alone.

\section{Disclosure statement}

No potential conflict of interest was reported by the author.

\section{Notes}

1. In the literature, three dimensions of state capacity are usually distinguished: coercive capacity, extractive capacity (raising revenues), and administrative capacity (producing and delivering public goods and services and regulating economic activity; Skocpol 1985, p. 16, Hanson and Sigman 2013). Environmental state capacity (but also regulating financial markets) concerns mainly the latter dimension, although it is dependent on extractive capacities.

2. There is growing work on indicators and databases for quantification of (administrative) state capacity (e.g. Hanson and Sigman 2013), but hardly on environmental state capacity. Brunel and Levinson (2013) and Sauter (2014) have assessed various existing and new conceptualisations to assess state environmental stringency, but have not yet carried out systematic applications.

3. The number of staff could not be traced for all OECD countries. Occasionally, ministries were reorganised - hence the later years (early 2000s) or absence of the country. In some (federal) nation states, environmental protection is more a responsibility of the states rather than the federal government.

\section{References}

Ahuis, C., 2004. Die Umweltpolitik in Deutschland nach 1945. Norderstedt: GRIN Verlag. Aldred, R., 2012. Governing transport from welfare state to hollow state: the case of cycling in the UK. Transport Policy, 23, 95-102. doi:10.1016/j.tranpol.2012.05.012

Andersen, M.S. and Liefferink, D., Eds., 1997. European environmental policy. The pioneers. Manchester: Manchester UP.

Anthoff, D. and Hahn, R., 2010. Government failure and market failure: on the inefficiency of environmental and energy policy. Oxford Review of Economic Policy, 26 (2), 197-224. doi:10.1093/oxrep/grq004 
Arnouts, R. and Arts, B., 2009. Environmental governance failure: the 'Dark Side' of an essentially optimistic concept. In: B. Arts, A. Lagendijk, and H. Van Houtum, eds. The disoriented state: shifts in governmentality, territoriality and governance. Heidelberg: Springer, 201-228.

Barrett, B.F.D., Ed., 2005. Ecological modernization in Japan. Abingdon: Routledge.

Beck, U., 2005. Power in the global age. A new global political economy. Cambridge: Polity.

Binder, M., 2002, Umweltpolitischen Basisinnovationen im Industrieländervergleich. Ein grafisch-statistischer Überblick, FFU-Report 02-06, Berlin: Environmental Policy Research Centre

Bouteligier, S., 2013. Global cities and networks for global environmental governance. spaces of innovation, places of leadership. Abingdon: Routledge.

Brunel, C. and Levinson, A., 2013. Measuring environmental regulatory stringency, OECD Trade and Environment Working Papers 2013/05, Paris: OECD

Busch, P.-O., Jörgens, H., and Tews, K., 2005. The global diffusion of regulatory instruments: the making of a new international environmental regime. The Annals of the American Academy of Political and Social Science, 598, 146-167. doi:10.1177/ 0002716204272355

Bush, S.R., et al., 2013. Certify sustainable aquaculture?. Science, 341 (6150), 10671068. doi:10.1126/science. 1237314

Castells, M., 2009. Communication power. Oxford, NY: Oxford University Press.

Castree, N., 2008. Neoliberalising nature: processes, effects, and evaluations. Environment and Planning A, 40, 153-173. doi:10.1068/a39100

Collier, U., Ed.., 1997. Deregulation in the European union. Environmental perspectives. London: Routledge.

Conca, K., 2005. Old states in new bottles? The hybridization of authority in global environmental governance. In: J. Barry and R. Eckersley, eds. The state and the global ecological crisis. Cambridge, MA: MIT, 181-205.

Cutler, A.C., Haufler, V., and Porter, T., 1999. The contours and significance of private authority in international affairs. In: A.C. Cutler, V. Haufler, and T. Porter, eds. Private authority and international affairs. New York, NY: New York State University Press, 333-376.

Eckersley, R., 2004. The green state. rethinking democracy and sovereignty. Cambridge, MA: MIT.

Enros, P., 2013. Environment for science: a history of policy for science in environment Canada. Toronto: Self-published using CreateSpace (an Amazon.com Company).

Esty, D.C. and Porter, M.E., 2005. National environmental performance: an empirical analysis of policy results and determinants. Environment and Development Economics, 10 (4), 391-434. doi:10.1017/S1355770X05002275

European Commission/Eurostat, 2011. Environmental protection expenditures in Europe, 1995-2009 data. Luxembourg: Publications Office of the European Union.

Eurostat (2014) Environmental protection expenditure, Brussels: Eurostat, Available from: http://epp.eurostat.ec.europa.eu/statistics_explained [Accessed 5 October 2014].

Falkner, R., 2003. Private environmental governance and international relations: exploring the links. Global Environmental Politics, 3, 72-87. doi:10.1162/ 152638003322068227

Gereffi, G., Garcia-Johnson, R., and Sasser, E., 2001. The NGO-industrial complex. Foreign Policy, 125, 56-65. doi:10.2307/3183327

Glasbergen, P., Biermann, F., and Mol, A.P.J., Eds., 2007. Partnerships, governance and sustainable development. Reflections on theory and practice. Cheltenham: Edward Elgar.

Glin, L.C., et al., 2012. Governing the transnational organic cotton network from Benin. Global Networks, 12 (3), 333-354. doi:10.1111/j.1471-0374.2011.00340.x 
Haas, P.M., Keohane, R.O., and Levy, M.A., Eds., 1993. Institutions for the earth. Sources of environmental protection. Cambridge, MA: MIT.

Hanson, J.K. and Sigman, R. (2013), Leviathan's Latent Dimensions: Measuring State Capacity for Comparative Political Research, Unpublished Manuscript, Syracuse University, Available from http://faculty.maxwell.syr.edu/johanson/papers/hanson_sig man13.pdf [Accessed October 2014].

Hays, S.P., 1987. Beauty, health, and permanence: environmental politics in the United States, 1955-1985. Cambridge: Cambridge UP.

Helm, D., 2010. Government failure, rent-seeking, and capture: the design of climate change policy. Oxford Review of Economic Policy, 26 (2), 182-196. doi:10.1093/ oxrep/grq006

Hey, C., 2002. Why does environmental policy integration fail? The case of environmental taxation for heavy goods vehicles. In: A. Lenschow, ed. Environmental policy integration. greening sectoral policies in Europe. London: Earthscan, 127-152.

Hillstrom, K. and Hillstrom, L., 2010. U.S. environmental policy and politics: a documentary history. Washington, DC: CQ press.

Hsu, A., et al., 2014. The 2014 environmental performance index. New Haven, CT: Yale Center for Environmental Law and Policy.

Jacob, K. and Volkery, A., 2006. Modelling capacities for environmental policy-making in global environmental politics. In: M. Jänicke and K. Jacob, eds. Environmental governance in global perspective. New approaches to ecological and political modernisation. Berlin: Freie Universität, FFU report 01-2006, 67-94.

Jänicke, M., 1986. Staatsversagen. Die Ohnmacht der Politik in die Industriegesellschaft. München: Piper.

Jänicke, M., 1993. Über ökologische und politische Modernisierungen. Zeitschrift Für Umweltpolitik Und Umweltrecht, 2, 159-175.

Jordan, A., Bauer, M.W., and Green-Pedersen, C., 2013. Policy dismantling. Journal of European Public Policy, 20, 795-805. doi:10.1080/13501763.2013.771092

Jordan, A. and Lenschow, A., 2010. Environmental policy integration: a state of the art review. Environmental Policy and Governance, 20 (3), 147-158. doi:10.1002/eet. v20:3

Knill, C., Tosun, J., and Bauer, M.W., 2009. Neglected faces of Europeanization. Public Administration, 87 (3), 519-537. doi:10.1111/j.1467-9299.2009.01768.x

Korte, S. and Jörgens, H., 2012. Active dismantling under high institutional constraints?. In: M.W. Bauer, A. Jordan, C. Green-Pedersen, and A. Héritier, eds. Dismantling public policy. Oxford: Oxford University Press, 81-102.

Kraft, M.E. and Vig, N.J., 2010. Environmental policy over four decades. Achievements and new directions. In: N.J. Vig and M.E. Kraft, eds. Environmental policy. New directions for the twenty-first century. 7th ed. Washington, DC: CQ Press, pp.1-26.

Lenschow, A., 2002. New regulatory approaches in 'Greening' EU policies. European Law Journal, 8 (1), 19-37. doi:10.1111/eulj.2002.8.issue-1

Levy, J.D., 2010. Welfare retrenchment. In: F.G. Castles, S. Leibfried, J. Lewis, H. Obinger, and C. Pierson, eds. The oxford handbook of the welfare state. Oxford: Oxford University Press, 552-568.

Liberatore, A., 1997. The integration of sustainable development objectives into EU policy-making: Barriers and prospects. In: S. Baker, M. Kousis, D. Richardson, and S. Young, Eds. The politics of sustainable development: theory, policy and practice within the European Union. London: Routledge, 107-126.

Mann, M., 1984. The autonomous power of the state: its origins, mechanisms and results. European Journal of Sociology, 25 (2), 185-213. doi:10.1017/ S0003975600004239 
Mayer, F. and Gereffi, G., 2010. Regulation and economic globalization: prospects and limits of private governance. Business and Politics, 12 (3), article 11 doi:10.2202/ 1469-3569.1325

McCormick, J., 1991. British politics and the environment. London: Earthscan.

Meadowcroft, J., 2005. From welfare state to ecostate. In: J. Barry and R. Eckersley, eds. The state and the global ecological crisis. Cambridge, MA: MIT, 3-23.

Meadowcroft, J., 2007. Democracy and accountability: the challenge for cross-sectoral partnerships. In: P. Glasbergen, F. Biermann, and A.P.J. Mol, eds. Partnerships, governance and sustainable development. reflections on theory and practice. Cheltenham: Edward Elgar, 194-213.

Mercer, D., Christesen, L., and Buxton, M., 2007. Squandering the future-climate change, policy failure and the water crisis in Australia. Futures, 39 (2-3), 272-287. doi:10.1016/j.futures.2006.01.009

Mert, A., 2012. Partnerships and the privatisation of environmental governance: on myths, forces of nature and other inevitabilities. Environmental Values, 21 (4), 475-498. doi:10.3197/096327112X13466893628148

Mol, A.P.J., 2004. Balancing the call for environmental integration. In: F. Gökşen, O. Seipel, and M. Brien, et al., Eds.. Integrating and articulating environments: a challenge for northern and southern Europe. Lisse: Swets \& Zeitlinger, 143-162.

Mol, A.P.J., 2007b. Bringing the environmental state back in: partnerships in perspective. In: P. Glasbergen, F. Biermann, and A.P.J. Mol, eds. Partnerships, governance and sustainable development. Reflections on theory and practice. Cheltenham: Edward Elgar, 214-236.

Mol, A.P.J., 2009. Environmental deinstitutionalization in Russia. Journal of Environmental Policy and Planning, 11 (3), 223-241. doi:10.1080/ 15239080903033812

Mol, A.P.J., 2010. Environmental authorities and biofuel controversies. Environmental Politics, 19 (1), 61-79. doi:10.1080/09644010903396085

Mol, A.P.J. and Buttel, F.H., Eds, 2002. The environmental state under pressure. Amsterdam: Elsevier.

Müller, E., 2002. Environmental policy integration as a political principle: the German case and the implications of European policy. In: A. Lenschow, ed. Environmental policy integration. greening sectoral policies in Europe. London: Earthscan, 57-77.

Ohmae, K., 1995. The end of the nation state. The rise of regional economics. London: HarperCollins.

Paehlke, R. and Torgerson, D., Eds, 1990. Managing leviathan: environmental politics and the administrative state. Petersborough (Ont.): Broadview Press.

Pattberg, P., 2007. private institutions and global governance. The new politics of environmental sustainability. Cheltenham: Edward Elgar.

Rauch, J. and Evans, P., 2000. Bureaucratic structure and bureaucratic performance in less developed countries. Journal of Public Economics, 75 (1), 49-71. doi:10.1016/S00472727(99)00044-4

Rosenbaum, W.A., 2000. Escaping the 'battered agency syndrome': EPA's gamble with regulatory reinvention. In: N.J. Vig and M.E. Kraft, Eds.. Environmental policy. 4th ed. Washington, DC: CQ Press, 165-189.

Sassen, S., 2006. Territory-authority-rights. From medieval to global assemblages. Princeton, NJ: Princeton University Press.

Sauter, C., 2014. How should we measure enviornmental policy stringency? A new approach. Neuchatel: Institute of Economic Research, University of Neuchatel.

Seidman, G., 2005. Stateless' regulation and consumer pressure: Historical experiences of transnational corporate monitoring. In: F.H. Buttel and P. McMichael, eds. New 
directions in the sociology of global development. Bingley: Emerald Group Publishing, 175-207.

Skocpol, T., 1985. Bringing the state back in: strategies of analysis in current research. In: P. Evans, et al., Eds. Bringing the state back in. Cambridge: Cambridge UP, 3-37.

Spaargaren, G. and Mol, A.P.J., 2008. Greening global consumption: redefining politics and authority. Global Environmental Change, 18 (3), 350-359. doi:10.1016/j. gloenvcha.2008.04.010

Spaargaren, G., Mol, A.P.J., and Buttel, F.H., Eds, 2006. Governing environmental flows. Global challenges for social theory. Cambridge, MA: MIT.

Steinberg, P.F. and VanDeveer, S.D., Eds., 2012. Comparative environmental politics. Theory, practice, and prospects. Cambridge, MA: MIT.

Strange, S., 1996. The retreat of the state: the diffusion of power in the world economy. Cambridge: Cambridge UP.

Tysiachniouk, M.S., 2012. Transnational governance through private authority. The case of the forest stewardship council certification in Russia. Wageningen: Wageningen Academic Publishers.

UNEP, 2012. Global environmental outlook 5. Nairobi: UNEP.

Van Tatenhove, J., Arts, B., and Leroy, P., Eds, 2000. Political modernisation and the environment. The renewal of environmental policy arrangements. Dordrecht: Kluwer.

Vig, N.J. and Kraft, M.E., Eds., 2010. Environmental policy. New directions for the twenty-first century, 7th ed. Washington, DC: CQ Press.

WEF (World Economic Forum), 2014. The global competitiveness report 2014-2015, Geneva: WEF

Weiburst, I., 2009. Green leviathan: the case for a federal role in environmental policy. Farnham: Ashgate.

Weidner, H. and Jänicke, M., Eds., 2002. Capacity building in national environmental policy: a comparative study of 17 countries. Berlin: Springer. 